\title{
Mantle xenoliths from the Jetty Peninsula area (East Antarctica): samples of thermally eroding lithosphere on the flanks of the Lambert-Amery Rift
}

\author{
Andronikov, A.V. ${ }^{1,2}$, Foley, S.F. ${ }^{1}$ and Melzer, S. ${ }^{3}$ \\ 1. Mineralogisch-Petrologisches Institut, Universität Götingen, Goldschmidtsr.1, D-37077 Göttingen, Germany \\ 2. VNIIOkeangeologia, Abgliyski Ave. 1, 190121 St.Petersburg, Russia \\ 3. GeoForschungsZentrum Potsdam, Postfach 600751, D-14407 Potsdam, Germany
}

The Lambert-Amery rift is the principal tectonic feature in East Antarctica, forming a significant recess in the coastline between $65^{\circ}$ and $75^{\circ} \mathrm{E}$, and is occupied to a large extent by the Lambert Glacier and Amery Ice Shelf. It is flanked by mid-Proterozoic amphibolite- to granulite facies rocks (known as the Rayner Complex; Sheraton et al., 1980) forming the northern Prince Charles Mountains on the western side of the rift. Archean basement is found adjacent to the rift in the continental interior (southern Prince Charles Mountains; Tingey, 1982) and further from the rift in Enderby Land to the west and in the Vestfold Hills to the east.

Magmatic activity associated with the rift occurred episodically over a prolonged period from 460 to $40 \mathrm{Ma}$ (Andronikov et al., 1998). Mantle peridotite xenoliths occur in ultramafic alkaline dykes and stocks of Jurassic age in the Jetty Peninsula area at the northwestern margin of the rift close to the Amery Ice Shelf, and in trachybasaltic volcanics of the Manning Massif in the northern Prince Charles Mountains. The present study concerns xenoliths from two intrusive bodies from the Jetty Peninsula area.

The following three main groups of peridotite xenoliths can be identified on the basis of mineral composition and textures.

1) Homogeneous spinel lherzolites (HSL) are characterised by homogeneous mineral compositions and lack any pronounced textural indication of reaction between mineral phases or with any infiltrating melt or fluid.

2) Inhomogeneous spinel lherzolites (ISL) contain recrystallised mineral rims which differ in major element composition from the cores. These features are interpreted to indicate reaction with an infiltrating melt.

3) Inhomogeneous garnet-spinel lherzolites (IGSL) show the texural characteristics of the ISL, but additionally contain garnet. Spinel is relatively rare in this group, and the garnet is commonly replaced by kelyphite rims to a large extent.

All groups contain very little in the way of accessory phases, of which the most common is amphibole. Silicate glass is found in some samples, and is believed to partly represent migrating melt that existed within the rocks prior to sampling by the host magmatic rock.

The HSL group are fairly uniform in modal mineralogy and mineral chemistry (Table 1), and are typical of peridotites from the non-cratonic continental lithosphere in being depleted in basaltic major element components relative to model primitive upper mantle. The ISL xenoliths differ in showing zonation of mineral compositions (Table 1) manifested in rims to clinopyroxenes with numerous small glass inclusions resulting in a "spongy" appearance. Rims are also, but less commonly, seen in spinel. Clinopyroxene rims show an increase in $\mathrm{Mg} \#(100 \mathrm{Mg} /(\mathrm{Mg}+\mathrm{Fe}))$ and a decrease in $\mathrm{Na}_{2} \mathrm{O}$ and $\mathrm{Al}_{2} \mathrm{O}_{3}$ relative to the cores, whereas spinels show an increase in $\mathrm{Cr}_{2} \mathrm{O}_{3}$ content. Garnet-bearing xenoliths (the IGSL group) also contain spinel, but spinel is much rarer than in the other two groups and is subordinate to garnet. Most garnets are typical pyrope-rich lherzolitic garnets with 5-6wt\% $\mathrm{CaO}$, although several analyses have much lower $\mathrm{CaO}$ (as low as $1.96 \mathrm{wt} \%$ ), which must indicate disequilibrium, because these samples also contain abundant clinopyroxene. Further chemical features of the rock-forming minerals and ranges of mineral modes for each xenolith group are given in Table 1 . 
Table 1: Modal proportions of minerals and main major element chemical features of the three Jetty Peninsula lherzolite groups.

(c=core; $r=$ rim)

\begin{tabular}{|c|c|c|c|}
\hline & $\begin{array}{l}\text { Homogeneous } \\
\text { Spinel Lherzolite }\end{array}$ & $\begin{array}{l}\text { Inhomogeneous } \\
\text { Spinel Lherzolite }\end{array}$ & $\begin{array}{l}\text { Inhomogeneous } \\
\text { Garnet-Spinel Lherzolite }\end{array}$ \\
\hline $\begin{array}{l}\text { modal } \\
\text { proportions } \\
(\%)\end{array}$ & $\begin{array}{ll}\text { Ol } & 78-82 \\
\text { Opx } & 10-14 \\
\text { Cpx } & 3.5-7.0 \\
\text { Sp } & 1.5-5.0\end{array}$ & $\begin{array}{ll}\text { Ol } & 66-75 \\
\text { Opx } & 11-16 \\
\text { Cpx } & 9-14 \\
\text { Sp } & 1-4\end{array}$ & $\begin{array}{ll}\text { Ol } & 57-68 \\
\text { Opx } & 18-22.5 \\
\text { Cpx } & 11-16.5 \\
\mathrm{Gt} & 1.5-6.8 \\
\mathrm{Sp} & 0.2-0.5\end{array}$ \\
\hline Olivine & Mg\# 90.8-91.4 & Mg\# $89.0-91.8$ & Mg\# 89.3-91.1 \\
\hline $\begin{array}{l}\text { Ortho- } \\
\text { pyroxene }\end{array}$ & Mg\# 91.3-92.3 & Mg\# 89.4-91.8 & $\begin{array}{r}\mathrm{Mg} \# 90.0-91.2(\mathrm{c}) \\
85.9-88.7(\mathrm{r})\end{array}$ \\
\hline $\begin{array}{l}\text { Clino- } \\
\text { pyroxene }\end{array}$ & $\begin{array}{l}\mathrm{Mg} \# 91.7-94.1 \\
\mathrm{Na} 2 \mathrm{O} 0.59-0.8 \%\end{array}$ & $\begin{array}{cl}\mathrm{Mg \#} & 88.5-92.0(\mathrm{c}) \\
& 90.0-92.4(\mathrm{r}) \\
\mathrm{Na} 2 \mathrm{O} & 1.13-2.06 \%(\mathrm{c}) \\
& 0.28-0.88 \%(\mathrm{r})\end{array}$ & $\begin{array}{ll}\mathrm{Mg \#} & 88.9-91.2(\mathrm{c}) \\
& 89.4-91.2(\mathrm{r}) \\
\mathrm{Na} 2 \mathrm{O} & 1.20-1.60 \%(\mathrm{c}) \\
& 0.35-0.59 \%(\mathrm{r})\end{array}$ \\
\hline Spinel & $\begin{array}{l}\mathrm{Mg} \# 66.0-78.7 \\
\mathrm{Cr} \# 25.7-33.9 \\
\mathrm{Fe} 3 * / \mathrm{Fe} 2+0.05-0.39\end{array}$ & $\begin{array}{cl}\mathrm{Mg} \# & 73.1-81.8(\mathrm{c}) \\
& 77.0-81.4 \AA \\
\mathrm{Cr} \# & 20.0-28.4(\mathrm{c}) \\
& 28.4-32.5 \AA \\
\mathrm{Fe} 3 * / \mathrm{Fe} 2+0.22-0.45(\mathrm{c}) \\
& 0.31-0.40(\mathrm{r})\end{array}$ & $\begin{array}{cc}\mathrm{Mg} \# & 75.9-83.1(\mathrm{c}) \\
& 76.4-78.6(\mathrm{r}) \\
\mathrm{Cr} \# & 13.1-30.7(\mathrm{c}) \\
& 18.4-30.5 \AA \\
\mathrm{Fe} 3+/ \mathrm{Fe} 2+0.10-0.41(\mathrm{c}) \\
\\
0.30-0.39(\mathrm{r}) \\
\end{array}$ \\
\hline Garnet & absent & absent & $\begin{array}{l}\mathrm{MgO} 20.1-26.8 \% \\
\mathrm{FeO} 6.28-8.75 \% \\
\mathrm{CaO} 5.04-5.70 \%(1.96) \\
\mathrm{Cr} 2 \mathrm{O} 31.11-2.00 \%\end{array}$ \\
\hline
\end{tabular}

The garnet-bearing IGSL group consistently show more fertile compositions than the HSL, whereas the ISL show the widest range, probably as a result of varying amounts of depletion by basalt loss and also of refertilisation by infiltrating melt, as manifested in the inhomogeneity of mineral compositions. The xenolith suite thus broadly shows a correlation of increasingly depleted character with decreasing depth, which is the pattern expected to originate by melt loss beneath a spreading ridge. Thermobarometric estimates of temperature and pressure conditions from mineral chemistry indicate temperatures of around $1000-1150^{\circ} \mathrm{C}$ from the Wells (1977) thermometer for most xenoliths, whereas two correspond to much lower temperatures between 700 and $750^{\circ} \mathrm{C}$. Coupled with pressure estimates from the barometers of Nickel and Green (1985) and Köhler and Brey (1990), these lead us to the interpretation that two fossil geothermal gradients are represented by the xenolith suite: the two lower temperature samples reflect an earlier pre-rift sub-continental (but non-cratonic) geotherm, whereas the mineral chemistry of all other xenoliths corresponds to a later higher-temperature geotherm associated with the development of the Lambert-Amery Rift.

Isotopic studies of the xenoliths are currently available only in the form of Sm-Nd whole-rock isotopic measurements and and those on clinopyroxene and orthopyroxene mineral separates (Andronikov and Beliatsky, 1995). Although these results must be used with care, they have been interpreted to indicate times of isotopic disturbance of the mantle, possibly related to episodes of melt or fluid infiltration such as those marked by chemical and petrographic features in the xenoliths (Andronikov and Beliatsky, 1995). Sm-Nd whole-rocks appear to fall into two groups at ca. 0.9 and ca. $0.6 \mathrm{Ga}$. The "isochron" given by orthopyroxene from the HSL is older (ca. 1.2 Ga), apparently preserving information from before these enrichment episodes. Depleted mantle model ages range between 0.92 and $1.21 \mathrm{Ga}$, so that there is no longer any indication of material older than $1.2 \mathrm{Ga}$. The $1.2 \mathrm{Ga}$ limit may indicate previous thermal erosion of the lithosphere in the mid-Proterozoic. 
The Jetty Peninsula xenolith isotope data appear to indicate episodic infiltration of the lithosphere on the flanks of the developing rift. It is interesting to note that the age "modes" reported by Andronikov and Beliatsky (1995) of 0.9 and $0.6 \mathrm{Ga}$ correlate with well-known tectonic events in East Antarctica: $0.9 \mathrm{Ga}$ is characteristic for the Rayner metamorphism in crustal rocks adjacent to the Lambert-Amery rift, and is interpreted to indicate an episode of major crustal growth in a collisional setting (Sheraton et al., 1993). The "age" of $0.6 \mathrm{Ga}$ is approximately that of the later stages of the Ross Orogeny (Ravich et al., 1984), and is believed to record an earlier episode of rifting known as the Beaver Lake paleorift in the Lambert-Amery region.

In summary, the petrographic and chemical characteristics of the Jetty Peninsula peridotite xenoliths may represent samples of Antarctic mantle lithosphere of Proterozoic age which also record at least two episodes of refertilisation in major elements and enrichment in incompatible elements. The heat source for the generation of the host alkali-picrite was derived from the asthenosphere beneath the developing rift, and samples of the overlying lithosphere were taken during eruption from restricted areas which had previously experienced melt infiltration events at different times. The enriching agents can be taken as being silicate melts similar in origin and nature to the present alkali picrite host rock; the increase in $\mathrm{Mg \#}$ from cores to rims in the ISL group may indicate infiltration by a melt with high $\mathrm{Mg \#}$ which must take up Fe from the peridotite melts during infiltration in order to satisfy the $\mathrm{Mg} / \mathrm{Fe}$ equilibrium exchange coefficient.

\section{References}

Andronikov, A.V. and Beliatsky, B.V., 1995, Implication of Sm-Nd isotopic systematics to the events recorded in the mantle-derived xenoliths from the Jetty Peninsula, East Antarctica: Terra Antarctica 2, 103-110.

Andronikov, A.V., Foley, S.F. and Beliatsky, B.V., 1998, Sm-Nd and Rb-Sr isotope systematics of the East Antarctic Manning Massif alkaline trachybasalts and the development of the mantle beneath the Lambert-Amery rift: Mineral. Petrol. (in press).

Köhler, T. and Brey G.P., 1990, Ca-exchange between olivine and clinopyroxene as a geothermobarometer calibrated from 2 to $60 \mathrm{kbar}$ in primitive natural lherzolites: Geochim. Cosmochim. Acta 54, 2375-2388.

Nickel, K.G. and Green, D.H., 1985, Empirical geothermobarometry for garnet peridotites and implications for the nature of the lithosphere, kimberlites and diamonds: Earth Planet. Sci. Lett. 73, 158-170.

Ravich, M.G., Soloviev, D.S. and Fedorov, L.V., 1984, Geological structure of MacRobertson Land (East Antarctica): Amerind Publ., New Delhi, 230pp.

Sheraton, J.W., Tingey, R.J., Black, L.P. and Oliver, R.L., 1993, Geology of the Bunger Hills area, Antarctica: implications for Gondwana correlations: Antarctic Sci. 5, 85-102.

Tingey, R.J., 1982, The geological evolution of the Prince Charles Mountains - an Antarctic Archean cratonic block: in Craddock, C. ed., Antarctic Geoscience, Univ. Wisconsin Press, Madison, 455-464.

Wells, P.R.A., 1977, Pyroxene thermometry in simple and complex systems: Contrib. Mineral. Petrol. 62, 129-139. 